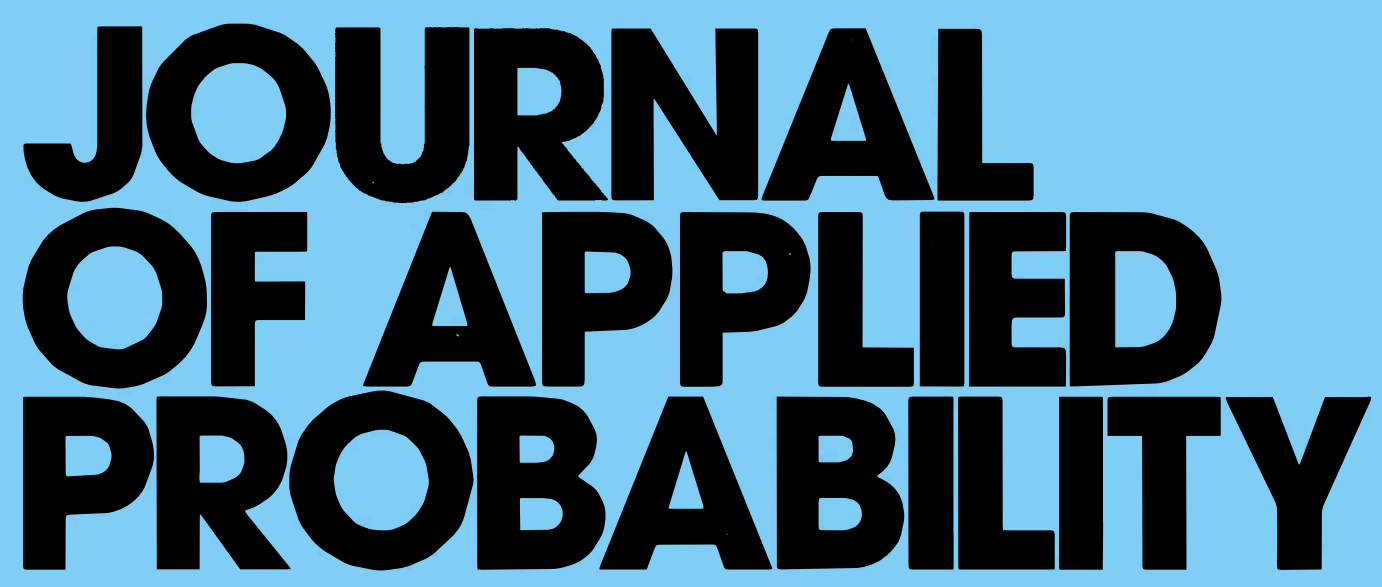

VOLUME 45

NUMBER 3

SEPTEMBER 2008

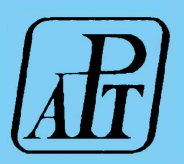

EDITOR-IN-CHIEF S. ASMUSSEN

FOUNDING EDITOR (1964-1989) J. GANI

PAST EDITOR-IN-CHIEF (1990-2007) C. C. HEYDE 


\section{JOURNAL OF APPLIED PROBABILITY}

This is an international journal published by the Applied Probability Trust in association with the London Mathematical Society; it contains research papers and notes on applications of probability theory to the biological, physical, social and technological sciences. An annual volume of up to 1200 pages is published in four issues appearing in March, June, September and December.

\section{EDITORIAL BOARD}

Editor-in-Chief

Coordinating Editors

Editors
S. ASMUSSEN (Aarhus Universitet)

N. H. BINGHAM (Imperial College London)

P. JAGERS (Chalmers University of Technology and Göteborgs Universitet)

R. J. ADLER (Technion, Haifa)

T. AVEN (University of Stavanger)

F. BACCELLI (ENS, Paris)

J. D. BIGGINS (University of Sheffield)

J. BLANCHET (Columbia University)

D. J. DALEY (Australian National University)

P. EMBRECHTS (ETH, Zürich)

S. FOSS (Heriot-Watt University)

P. W. GLYNN (Stanford University)

O. HÄGGSTRÖM (Chalmers University of Technology)

S. JANSON (Uppsala Universitet)

F. C. KLEBANER (Monash University)

C. KLÜPPELBERG (Technische Universität München)

S. G. KOU (Columbia University)

A. E. KYPRIANOU (University of Bath)

T. MIKOSCH (Københavns Universitet)

A. MÜLLER (Heriot-Watt University)

S. I. RESNICK (Cornell University)

L. C. G. ROGERS (University of Cambridge)

M. SCARSINI (Università di Torino)

M. SCHWEIZER (ETH, Zürich)

A. L. STOLYAR (Alcatel-Lucent)

P. G. TAYLOR (University of Melbourne)

J. L. TEUGELS (Katholieke Universiteit Leuven)

R. VAN DER HOFSTAD (Technische Universiteit Eindhoven)

R. R. WEBER (University of Cambridge)

W. WHITT (Columbia University)

\section{EDITORIAL OFFICE}

\section{Executive Editor}

Production Editor

\section{J. NASH (University of Sheffield)}

E. TALIB (University of Sheffield)

All correspondence relating to the submission of papers should be sent to: The Executive Editor, Applied Probability, School of Mathematics and Statistics, University of Sheffield, Sheffield S3 7RH, UK. Subscription rates and notes for contributors are to be found on the inside back cover. 